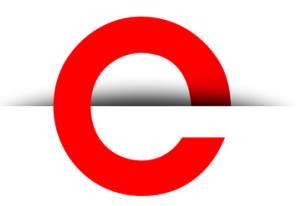

U T S

e PRES S

\section{PORTAL Journal of} Multidisciplinary International Studies

Vol. 16, No. 1/2

2019

(c) 2019 by the author(s). This is an Open Access article distributed under the terms of the Creative Commons Attribution 4.0 International (CC BY 4.0) License (https:// creativecommons.org/licenses/ by/4.0/), allowing third parties to copy and redistribute the material in any medium or format and to remix, transform, and build upon the material for any purpose, even commercially, provided the original work is properly cited and states its license.

Citation: Suzuki, T. 2019.

Diasporic Mourning:

Commemorative Practices Among Okinawan Repatriates from Colonial Micronesia.

PORTAL Journal of

Multidisciplinary International

Studies, 16:1, 29-45.

http://dx.doi.org/10.5130/

portalv16i1/2.6276

PORTAL is published under the auspices of UTSePress, Sydney, Australia. ISSN: 14492490; http://epress.lib.uts.edu. au/ojs/index.php/portal

RESEARCH ARTICLE

\title{
Diasporic Mourning: Commemorative Practices Among Okinawan Repatriates from Colonial Micronesia
}

\section{Taku Suzuki}

Corresponding author: Associate Professor and Director, International Studies, Taku Suzuki, Denison University, 100 West College Street, Granville, Ohio 43023, USA.

Email: suzukitadenison.edu

DOI: http://dx.doi.org/10.5130/portalv16i1/2.6276

Article History: Received 25/08/2018; Revised 27/5/2019; Accepted 10/06/2019; Published $13 / 11 / 2019$

\begin{abstract}
Could colonial settlers who repatriated from colonies to metropole after the empire's fall be considered 'diaspora'? How do these migrants of decolonization maintain their collective memory of the past and solidary identity as a group? This article explores the historical experiences of Okinawan colonial migrants to the Japanese mandate of Micronesia (which includes the Northern Marianas, Palau, and Chuuk) and these migrants' forced repatriation to Okinawa after the devastating battles in the Western Pacific in 1944-1945. It also ethnographically examines the Okinawan repatriates' pilgrimages to the islands throughout the post-WWII years to visit their childhood homes and locations of their loved ones' deaths. These Okinawan repatriates, who had been twice-displaced in their lifetimes and survived the brutal war, continue to visit the islands to reminisce about their childhood and pray for the loved ones who had died on the islands. This article argues that such migrants of decolonization could not only be considered a diasporic group but also a group who retain a strong sense of solidarity and collective memory. Further, this article claims that formal and informal ritualistic practices, such as those ethnographically portrayed in this essay, play a pivotal role in creating and recreating collective memory and identity among the migrants of decolonization as a diaspora.
\end{abstract}


U T S

e PRES S

\section{Keywords:}

Diaspora; Postcolonialism; Identity; Memory; Okinawa; Micronesia

On Saipan where palm trees grew,

We were lovingly raised.

We were striving for a promising future.

Let's talk about it at the Southern Cross Club.

On the green plains of Tinian,

We proudly built a mound of sugar canes.

The world-renowned 'sugar island.'

Let's talk about it at the Southern Cross Club.

-A song sung at an informal gathering of the Minami-jüji-kai (Southern Cross Club), a group of Okinawan repatriates from the Japanese mandate of the Northern Mariana Islands.

On the evening of May 25, 2015, the welcome reception was held for the $46^{\text {th }}$ annual pilgrimage by the members of Nan'yō Guntō Kikansha-kai, or the Micronesia Repatriates' Association of Okinawa (MRA). ${ }^{1}$ The reception was hosted by the mayor of Saipan of the Commonwealth of the Northern Mariana Islands (CNMI). The president of the MRA thanked the hospitality shown by the mayor and the people of Saipan. He then said as follows:

I grew up on this island, and consider this place to be my second ... no, my first home.

I have come to this island [after repatriating to Okinawa] numerous times to pray for my sister and father who were killed during the war. Every time we come here, people greet us by saying, "Welcome home!"We the repatriates consider you, the islanders, to be our konpanī, dear friends.

In 2015, a pilgrimage of approximately 90 Okinawan repatriates and their family members traveled to the Saipan and Tinian islands of CNMI and joined 'the ceremony to pacify/console the spirits of the dead' (ireisai) who had died in the Battle of the Marianas in 1944. The pilgrims toured the key sites that are relevant to both he Okinawan colonial immigrants and the battle. During the limited free time they had during the packed itinerary of the four-day tour, the pilgrims visited the remains of their former residences and elementary schools, often assisted by the children and grandchildren of the Indigenous islanders they had befriended during the colonial era.

Taking a cue from recent scholarly works on the postcolonial migration of former colonists after the fall of empires (Borutta \& Jansen 2016; Buettner 2016; Shimamura 2013; Smith 2002a; Tamanoi 2009; Watt 2009), this article examines the experiences of Okinawan repatriates from the Japanese mandate of Micronesia. More specifically, it focuses on the Northern Mariana Islands after World War II in relation to the 'migration of decolonization' (Smith 2002b: 26). It provides a historical overview of Okinawan migration to the Northern Marianas under Japanese rule and the migrants' forced return to Okinawa immediately after the war. This was the period during which the Okinawan colonial migrants and repatriatesalong with the French, Dutch, German, and Portuguese migrants of decolonization-

1 Kikansha-kai literally means 'association of the returnees.' However, the official English translation of the organization's name says 'repatriates,' so this essay also refers to the members as repatriates. 
witnessed 'considerable brutality' during the Battle of the Marianas, departed from their long-time 'home' on the Mariana Islands 'in the context of the utmost chaos,' and underwent 'difficult incorporation ... into [local] communities' after their 'return' to metropolitan homes (Smith 2002b: 16, 27). Thus, this article argues that the Okinawan repatriates from colonial Micronesia match Robin Cohen's foundational definition of 'diaspora' (1997: 26-27) as a population displaced and/or dispersed from their homeland, who remain nostalgically connected to their often-idealized homeland and maintain a strong collective identity and memory, often over generations.

This article then ethnographically examines a practice by which Okinawan repatriates maintain what Zeruvabel (1996) calls a 'mnemonic community.' I suggest that the Okinawan repatriates' mnemonic community is underpinned by their shared sorrow about their displacement, their desire to connect to the romanticized past 'home,' and their mourning for lost lives. It describes an irei (a ritual to pacify or console the spirits/souls of the dead) pilgrimage to the CNMI as a key mnemonic device that helps the Okinawan repatriates and their offspring shape a solidary identity through spatial practices. Namely, these practices are formal and informal ritualistic performances to remember the past and mourn for the war dead. These ethnographic 'snapshots' suggest that diasporic communities of colonial repatriates can be maintained when the communities are drawn from more than nostalgia for the homes from which they were displaced but instead from a profound sense of loss, often underpinned by the deaths that continue to haunt the living.

This article is based on the data I obtained between 2013 and 2015. I conducted approximately 50 structured and unstructured interviews with Okinawan repatriates from the Northern Marianas, along with 10 children of the repatriates who had participated in the irei tours to the islands. I also conducted participant-observations of numerous formal MRA-related meetings and informal community gatherings, and I participated in the MRA's irei pilgrimages to Saipan and Tinian in 2014 and 2015, during which time I had informal conversations with the Okinawan visitors. To protect the informants' identities, the names that appear in this article are all pseudonyms.

\section{Migrants of Decolonization as a Diaspora}

One of my contentions in this article is that Okinawan colonial migrants, who 'returned' to Okinawa after the war and decolonization, are diasporic subjects. Smith (2002a) calls the migrants of decolonization 'invisible migrants,' for despite their considerable scale and historical significance, they have garnered little scholarly attention or exerted little influence on theoretical development in migration studies. Two edited volumes, Europe's Invisible Migrants, edited by Smith (2002a), and Vertriebene and Pieds-Noirs in Postwar Germany and France: Comparative Perspectives, edited by Borutta and Jansen (2016), contain some of the few comprehensive studies on postcolonial repatriates and returnees to Europe.

Cooper points out that this form of migration was 'not just a migration among many others'; it was historically significant as a 'sudden, mass movement caused by a political crisis in a place' and was 'profoundly affected by the demise of the category of empire' (Cooper 2002: 172). Buettner (2016), for instance, comparatively chronicles the repatriation and resettlement processes of the British, Dutch, Belgian, French, and Portuguese. Smith's volume introduces such studies as Willems' (2002) study on Dutch migrants from the former East Indies (now Indonesia); Jordi's (2002) examination of French repatriates from Algeria, or pieds-noirs, resettling in Marseilles in the early 1960s; and Lubkemann's (2002) historical inquiry into 
Portuguese returnees, or retornados, from Angola and Mozambique. These works allow me to surmise that there are similar characteristics between European migrants of decolonization and Okinawan repatriates after their 'return' to 'home.' Both groups suffered from what Lubkemann refers to as becoming 'internal strangers' (2002: 76) in their metropolitan homeland upon their return. In line with this, Borutta and Jansen's volume compares the experiences of German vertriebene, or 'expellees,' from Eastern Europe with those of French pieds-noirs returning from Algeria. For example, Schwartz (2016) compares East and West German state policies for absorbing expellees into society, Ahonen (2016) analyses the political functions of German expellee organizations, and Weger (2016) investigates German expellee associations' commemorative practices and their symbolic communication to express German expellees' heritages. According to these studies, both the German expellees and French repatriates migrated to their metropolitan homeland en masse in a relatively short period of time, causing a great socioeconomic strain on the host societies, especially because the repatriates, having just escaped from political upheaval and/or war, had little material resources to re-establish their lives.

Smith's introductory chapter in Europe's Invisible Migrants claims that the repatriates or returnees from the former colonies to European metropoles can be viewed as a diaspora. Smith lists key common features, drawn from Cohen's criteria for diaspora (1997:26): 1) dispersal from an original homeland; 2) expansion from a homeland in search of work or trade or to further colonial ambitions; 3) collective memory and myth about the homeland; 4) idealization of the putative 'home' and a collective commitment to its maintenance, restoration, or creation; 5) the development of a return movement to its homeland; 6) a troubled relationship with host societies; 7) a sense of empathy and solidarity with other members; and 8) the possibility of a distinctive, creative, enriching life in host countries. Smith found that European migrants of decolonization satisfy most of those criteria but expressed doubt about the longevity of the collective memory and identity. Similarly, Schwartz (2016: 82) claims that by 1960, German expellees who had resettled in West Germany already considered themselves as settled down in their new homeland.' Also, Cohen observes that by the late 1990s, the older generation of pieds-noirs was 'slowly disappearing and the younger one [was] not as committed to the memory of Algérie françaiseís' (2002: 144).

Smith calls for an expanded scope of inquiry into the invisible migrants of decolonization, such as Japanese repatriates from its colonies (2002b: 29-30). Indeed, there have been few English publications about these invisible migrants, let alone publications that attempt to approach these migrants as diasporas. Notable exceptions are Tamanoi's (2009) monograph on the orphaned Japanese civilians who repatriated from northeast China and Lori Watt's (2009) historical inquiry into Japanese and Okinawan repatriation after WWII. My study seeks to answer Smith's call by examining the Okinawan migrants of decolonization from the Japanese mandate of Micronesia. My first argument in this article is, thus, that Okinawan colonial migration to Japanese mandate of Micronesia from the 1920s to the early 1940s, and the abrupt mass 'return' of the Okinawan colonists to Okinawa in 1945-1946 is a diasporic phenomenon. The Okinawans have dispersed from their original homeland (i.e., Okinawa and then Micronesia) for work but continue to foster collective memory and solidary identity based on their idealized and nostalgized notion of childhood 'home.' This is due in part to a challenging period of re-establishing their socioeconomic status after their forced repatriation to Okinawa after WWII. 


\section{Mnemonic Community Formation and Maintenance}

The second argument I attempt to make in this article is that Okinawan repatriates form and maintain a sense of community based on their collective memory of the colonial past. As both Smith's and Borutta and Jansen's volumes emphasize, the formation and maintenance of collective memory of the colonial homeland is a crucial element of repatriates' collective identity. In his groundbreaking work on collective memory, Halbwachs recognizes the critical role physical space plays in collective memory, as 'the image of a place conjures up thoughts about an activity of the group associated with that place' (1992: 54). Building on this insight, Olick proposes that one of the common 'mnemonic devices' (Olick 2003) that help a group create and maintain its collective past is a ritualistic spatial performance.

One such ritualistic performance conducted in a certain physical space is a commemorative ceremony or ritual. Numerous sociological and anthropological studies on national and religious identity formation, for instance, have examined how embodied collective performances, such as parades on national holidays and collective singing of a national anthem (Cerulo 1995; Connerton 1989; Spillman 1997), cater to collective memory production and the reproduction of national identity. Zerubavel (1996: 294) claims that through these collective actions, individuals undergo 'mnemonic socialization' that absorbs them into 'mnemonic communities.'This process involves 'the integration of various different personal pasts into a single common past that all members of a particular community come to remember collectively' (294). In short, then, collective mnemonic practices such as rituals and ceremonies serve as 'interactive opportunities to tune the symbolical repertoire of the mnemonic community, contextualizing the present through the evaluation of the past' (Vélez 2008: 41).

One could consider group travel as such a performance. Graburn (1977) famously argued that group travel is akin to a collective ritual, in which participants together undergo a state of communitas: an intense feeling of solidarity and belonging (Turner 1973). As numerous ethnographic studies of pilgrimages (Badone \& Roseman 2004; Cohen 1992; Collins-Kreiner \& Kliot 2000; Collins-Kreiner \& Gatrell 2006; Eade \& Sallnow 1991; Frey 1998) suggest, a shared belief among the participants that they are on a collective mission, which purports to seek a more noble - religious or otherwise — purpose than touristic pleasure, produces a strong communal bond among them. Baussant (2016), while not drawing on the communitas concept or highlighting pilgrimages' role in creating one, examines the Pieds-Noirs' pilgrimages to a commemorative shrine, Théoule-sur-Mer, near Cannes in southern France. She argues that the pilgrimages 'brought together believers with their roots in the same diocese ... [and pilgrimages] draw on a host of different networks based on social ties and kinship and are often grounded in the past' (216). She recognizes the power of travel and a place, which together bring 'commemoration and heritage as a touchstone,' and argues that through a pilgrimage, 'various symbolic and concrete forms of memory give rise to practices of spatial appropriation and performative expression of social bonds founded on ties with both past and present' (225). My examination of Okinawan repatriates' performative practices during irei pilgrimages departs from the existing studies on migrants of decolonization by taking an ethnographic approach to the processes of 'spatial appropriation and performative expression of social bonds' (225) among the diasporic repatriates. I argue that the bonds are underwritten by the Okinawan spirituality, which posits that souls of those who have died tragically outside of their 'home' must be pacified, consoled, and retrieved from the locations of death. 
U T S

e PRES S

\section{Irei Pilgrimages by Japanese and Okinawans}

Japanese sociologists and religion scholars have studied the practice of going to former battlefields for the purpose of irei. This practice began after the San Francisco Peace Treaty between Japan and the former Allied states in 1951. After a series of negotiations between the Japanese and US governments, groups of Japanese travelled in 1953 to Pacific islands under US military rule, such as Saipan, Tinian (now CNMI), Wake and Guam (now unincorporated territories of the USA), Angaur and Peleliu (now the Republic of Palau), Iwo Jima and Minami-tori-shima (now Japanese territories) (Hamai 2008). Many of these trips, especially in the early years, involved the excavation, collection, and retrieval of the remains or bones of the war dead (Awazu 2010; Figal 2007; Kitamura 2005, 2009; Nishimura 2008a, 2008b).

In his attempt to conceptualize overseas battlefield pilgrimages among bereaved family members of the war dead, Nakayama (2008) argues that these trips show two key characteristics of Japanese and Okinawan assumptions about the souls of the dead. The first is that the souls of the war dead stay where they died, and the second is that these souls remain religiously 'unprocessed' and, as 'raw' souls, remain frozen in the time of their deaths (Nakayama 2008: 204-205). Pilgrimages to former battlefields enable the visitors to encounter the unprocessed souls, along with their bodily remains, frozen at the times and places of their deaths, and to bring them back to their rightful places - typically family tombs, shrines, or memorial markers in their hometowns - to properly honor their souls. Similarly, Nishimura $\underline{(2008 b)}$ says that overseas battlefield pilgrims are motivated by their desire to 'meet' the souls of the war dead and bring them home across the spatiotemporal distance. However, Nishimura also draws on Turner (1973) and Kitamura (2005) to argue that the pilgrims create a state of communitas, in which the bereaved family members develop a strong sense of solidarity, underpinned by shared sorrow, as together they seek spiritual connections with dead family members. Following these insights, this article argues that by pursuing intense spiritual communication with the war dead and achieving communal bonding with fellow pilgrims, the camaraderie among Okinawan repatriates in postwar Okinawa and their pilgrimages to the Marianas represent the repatriates' creation and preservation of collective identity and memory. Furthermore, the repatriates' bond is not only based on shared nostalgia; it is also underwritten by the common connection with the war dead with which the repatriates have attempted to re-unite through travel.

\section{Okinawan Postcolonial Repatriates as a Diaspora}

Japanese colonization of Nan'yō, or the Japanese mandate of Micronesia, created sizable diasporic Okinawan communities in the Marianas, Palau, and other Western Pacific islands. After its 1898 defeat in the Spanish-American War, Spain ceded Guam to the USA and sold the remaining northern islands of the Mariana Islands to Germany in 1899. Japan took over the islands that had been under German rule, including Northern Marianas, when in 1918, the Central Powers lost to the Triple Entente, which Japan had joined as a British ally. The Nan'yō Kōhatsu Kabushiki Kaisha (NNK, South Seas Development Company), a Japanese government-backed developer of the Northern Marianas, recruited Okinawans, who had struggled with severe poverty after Japan annexed the Ryūkyū Kingdom in 1879, as migrant laborers on the islands. The Japanese population of the Marianas, 60 percent of whom were Okinawans, exploded in the 1930s. In 1935, more than 19,000 Japanese lived on Saipan, as opposed to some 3,500 Indigenous islanders and some 200 Korean migrants. The majority of the Okinawans worked as farm laborers on NKK's sugar plantations; tuna fishermen; 
U T S

e PRES S

manual or clerical workers for the colonial government; or small retail business owners. Escaping from the economic destitution in Okinawa, the migrants appreciated their relative economic stability in colonial Marianas, even if they suffered from backbreaking farm labour in sugarcane fields and the NKK's exploitative labour practices. During my interviews with the Okinawan repatriates, they emphasised their parents' long working hours and taxing physical farm labour as well as their own busy days with numerous domestic chores, but they were quick to add that it was worthwhile because their lives were improving. The colonists were hardly well-off, but the repatriates favourably compared their lives to the living standards of those who stayed behind in Okinawa. They remembered that their parents had told them that unlike their counterparts living in Okinawa, they were lucky to be able to ride bikes to school, wear leather shoes and, most importantly, never go hungry, thanks to abundant fruits, livestock, fish and Japanese food items available at NKK-owned general stores (shuho), where they could purchase daily necessities on credit. For the Okinawan migrants, therefore, Micronesia, unlike Okinawa, provided economic security and stability, even if they were made possible by an exploitative colonial system.

During the Battle of Marianas in 1944, around 44,000 Japanese soldiers, 10,000 Japanese civilians (more than half of whom were Okinawans), and an estimated 1,000 Koreans and Indigenous islanders (combined) were killed. In the Japanese mandate of Micronesia, 13,000 Okinawans were estimated to have died in battle and its aftermath in 1944-1945 (Aniya 1995: 16). Many Okinawans died not only from the relentless shelling by the US fleets, but also from group suicides. Through the militaristic school education that emphasized unconditional loyalty to the emperor, many Okinawan colonists had come to believe that it was shameful to surrender to the enemy, and that had they been captured by the Americans, all men would be enslaved, tortured, and killed, and all women would be gang-raped, by the captors (Shimojima 2012). The survivors who had been captured by the Americans were interned in the displaced persons' camps on the islands, then were repatriated to Okinawa from January to December 1946 (Imaizumi 2005: 14). Approximately 33,000 Okinawans were sent to Okinawa (Aniya 1995: 13). When the repatriates were sent to Okinawa, their 'homeland' had just undergone its own devastating war in the spring of 1945, which killed about a quarter of the local population and decimated the prefecture's social infrastructure. For those who were born and/or raised in colonial Northern Marianas and who had just lost hard-earned economic stability there, migrating to the war-torn Okinawa to restart their lives, on top of overcoming the trauma of war and loss of family members in the Marianas, was a daunting prospect. In fact, a majority of Okinawans wished to remain in the Marianas and petitioned the US military government to allow them to resettle in Tinian after the war (Imaizumi 2005: 16; Irei 1995: 57), but this plan never materialized and all the diasporic Okinawans in colonial Micronesia were forcibly repatriated.

Diasporic Okinawans who were born and/or raised in the Mariana Islands but were repatriated to Okinawa after the war became what Lubkemann refers to as 'internal strangers' (2002: 76) in Okinawa. After arriving in Okinawa, those with no next of kin in Okinawa, or those whose family estates had been expropriated by the US military, had to spend months in temporary accommodation, forming what was referred to as Nan'yō Buraku, or the 'South Seas Ghetto,' in Koza City (Imaizumi 2005: 16). Masahide Kanemoto, ${ }^{2}$ who was born in Saipan but relocated to Okinawa as a teenager, lived in Koza's 'South Seas Ghetto' for six months because his family's inherited property in Kadena Village was taken over by the US military

2 The names appearing in this article are pseudonyms to protect the interviewees' identities. 
to build an airbase. The US military government of Okinawa, which needed a large number of laborers to build and operate the fast-expanding military bases, became a major employer of the repatriates from the former Japanese colonies, such as Micronesia, the Philippines, and Taiwan (Toriyama 2013: 43).

As a diasporic group, the repatriates felt alienated in their own 'homeland' by having to work under a foreign occupier, the US military. Many of the male repatriates I interviewed joined the fast-increasing number of Okinawans working in US military jobs as soon as they were able, while also maintaining small farms in their home villages. They were attracted by the higher paying jobs and the many opportunities to obtain overstocked construction materials or discarded canned food from the facilities. Some female repatriates also worked at the US military bases as house maids, laundresses, and sales clerks at product exchange stores on the bases. The repatriates from the Marianas, who had already worked under the Americans while they were in the civilian internment camps in Saipan and Tinian before repatriation, could find military work in Okinawa with relative ease, but they did not enjoy it. The Okinawan military workers were not only profoundly ambivalent about their role in helping the foreign military occupy their home island; they were also resentful of what they perceived as American racism, such as the wage gap between American and Okinawan employees (Okinawa Taimusu Chūbu Shisha Henshū-bu 2013). The Okinawan repatriates, in other words, struggled to restart their lives in their own 'homeland,' and pined for their true 'home' in the Mariana Islands where they used to enjoy economic security and stability.

The repatriates from Micronesia also felt ostracized by the local Okinawans. A Japanese journalist learned that Nan'yō-gaeri, or 'returnees from South Seas,' were looked on with suspicion and pity (Shimojima 2012: 89). Toshiyuki Tōyama, a repatriate from Saipan, recalled feeling out of place in Okinawa, despite it being his 'home' (furusato), because everything was so unfamiliar to him (Saipan-kai 1994: 424). For example, as the repatriates grew up learning the standardized Japanese language in school and used it in the multi-ethnic colonial society, they had difficulty understanding the dialects spoken by other Okinawans. Although my Okinawan repatriate interviewees jokingly talked about this challenge, many were bullied by their classmates at Okinawan schools because they could not speak the dialect accurately. Kensei Aniya, a repatriate who grew up in Saipan, tried hard to learn the Okinawan vernacular by writing down the words and expressions his classmates taught him. He later learned that these words were all 'bad words,' and he was reprimanded by adults when he unsuspectingly used them. Hideko Tōma, who was born in Saipan and repatriated to Okinawa when she was ten, also bitterly remembered that she was mercilessly bullied in her family's home village by her school classmates, who took advantage of her lack of fluency in the local dialect.

Economically and socially marginalized in Okinawan society, the diasporic Okinawans who had returned from colonial Micronesia longed for their 'home' in the Western Pacific. Hundreds of Okinawan repatriates connected with other repatriates from colonial Micronesia and formed the MRA in February 1948 to launch a campaign for the US military government of Okinawa to permit them to re-migrate to the Northern Marianas (Imaizumi 2005: 28-30). According to the MRA's survey among the repatriates from the Japanese mandate of Micronesia, 94 percent of the respondents wanted to re-migrate there, and among them, 40 percent listed poverty as their primary reason. In contrast, about half of the respondents considered that material life in colonial Micronesia had been 'prosperous (yutaka), and less than ten percent thought that they had 'struggled (komatteita)' (Imaizumi 2005: 30). The respondents' nostalgia for the colonial Marianas was, in other words, rooted in their yearning for the socioeconomic conditions they had enjoyed before the war, pitted against their post- 
repatriation struggles in Okinawa. In war-ravaged Okinawa, a group of repatriates, led by a formerly successful business owner and the president of the Okinawan Association in Saipan during the colonial era, conducted the first ireisai in Okinawa and established MRA in 1948. In 1963, MRA began to organize pilgrimages to the Marianas and other Micronesian islands. In its peak years, a group of more than 1,000 Okinawans travelled together to the CNMI on an MRA-organized trip, and more than 6,000 Okinawans have joined the pilgrimages over the years.

Given this historical context, I suggest that the Okinawan repatriates from the Northern Marianas satisfy most, if not all, of Cohen's proposed criteria for a diaspora. What particularly stands out here is their continuing desire to return —even briefly— to the places of their birth and/or youth, even after having (re-)established a livelihood in postwar Okinawa. In the following section, I will ethnographically portray how the repatriates continue to maintain a strong collective identity and solidarity among themselves. In so doing, I argue that this collectivity is created and recreated through communal and ritualized travel, such as group pilgrimage. This collectivity is reinforced by the shared sense of loss of their 'homeland' and common experiences of their loved ones' deaths.

\section{Collective Memory and Identity (Re)construction: Ethnography of a Pilgrimage}

It emerged from the surveys and interviews I conducted with the participants in the 2014 pilgrimage to Saipan and Tinian of the CNMI that participants' objectives in traveling to the islands were to visit the places of their family members' deaths and 'retrieve' their souls, which many participants believed had not yet arrived in a peaceful after-world. The deaths of family members on battlefields present unique challenges to the living who seek to properly send the deceased to the after-world. For instance, the Vietnamese survivors of the Vietnam War viewed a dead body of a war victim who could not be retrieved for burial in a family tomb as 'the body of a nonperson,' and the soul of the dead was imagined to remain in 'the imagined state of tragic afterlife' (Kwon 2006: 13). Similarly, in his study of Okinawan rituals to mourn the victims of the Battle of Okinawa of 1945, Kitamura found that Okinawans who had lost their family members considered that the dead's souls were 'wandering around and looking for the help from the living relatives, because they could neither move into the after-world (gusō) nor could they return to this world' (Kitamura 2009: 235). Therefore, the Okinawans who could not retrieve their loved ones' bodies or bones tried to identify the locations of death to the best of their knowledge and conducted nujifa and unchike rituals, by which they tried to 'retrieve' these souls from the places of their deaths and transport them to their family tombs at home (Kitamura 2009: 239). The Okinawan pilgrims to the Northern Marianas have experienced the same agony, as many of them were unable to recover the bodies or bones of their family members who died during battle, let alone properly bury them in the family tombs in their home villages in Okinawa. During the pilgrimage, they conducted collective and personal rituals to encounter (and retrieve when possible) their dead relatives' souls and carry them home.

As a collective ritual, the official memorial ceremony is held at the northern edge of Saipan, where the Okinawan civilians retreated to and died during the battle by committing suicide. The ceremony in front of the Okinawa Memorial Marker (Okinawa-no-tō) consisted of speeches by the MRA leaders and local dignitaries. Then, all participants sang a Japanese folksong to a harmonica played by Mr Jinsei Nakamura, a repatriate from Saipan, who had lost 
his father and two siblings during the battle. During the 1944 battle, the Okinawan civilians retreated to the northern end of the island, and, fearing capture by the approaching US troops, hundreds died by jumping off a cliff or pulling the pins of grenades given to them by Japanese soldiers. The 2015 ceremony's MC was the MRA vice president, who began the program by emphasizing that the ceremony was not just for the Okinawan war victims but for all those who had died during the war. After a moment of silence and a prayer (offered by a Catholic priest from Saipan), the MRA president and a representative of the bereaved families, a son of the late former MRA president, gave speeches. The MRA president expressed his gratitude to the Saipan municipal government in particular, and locals in general, for keeping the memorial marker clean. He also thanked the spirits of the war dead for enabling the pilgrimages to continue over the years. Then, the former MRA president's son claimed that his father, who was his family's sole survivor from the 1944 battle, dedicated the rest of his life to 'console the spirits of the dead' and express 'his love of the Micronesian people'. As the pilgrims sang together, many were overcome by emotion and cried. Then, one by one, all the pilgrims partook in shōkō, a Buddhist ritual of pinching and burning powdered incense, the smell of which is meant to approximate the after-world, and held hands for a silent prayer in front of the memorial marker.

The pilgrims, many of whom did not know other participants before the trip, got to know each other during the trip and often formed an intimate bond, especially when they travelled together to their childhood homes and neighbourhoods, or the places of their family members' deaths. Their conversations usually began with the questions 'Where were you?' (ie, Where did you live before the war?) and 'Who died (ie, during the war)?' Such conversations led to pilgrims sharing their childhood memories of the colonial Marianas and how the pilgrims had survived the war, ending with an exchange of condolences for each other's losses. $\mathrm{Mr}$ Zenshō Igēe, a war orphan, and Mr Hiroshi Kinjō, who lost his sister during the war, had never met before the trip. Yet they took an excursion together to find their childhood homes in Tinian. They began exchanging childhood memories, which revealed remarkable anecdotal details, such as dance music at fall festivals, fishing trips with their fathers, and the smell of flowers in their backyards. Mr Igē joked that walking on Tinian's soil improved his otherwise deteriorating memory. ${ }^{3}$ Indeed, although Mr Kinjō was suffering from a recent leg injury, he was so eager to find his former family home's foundations that he walked into a rocky forest, disregarding his accompanying children's concern.

Nearly all participants spent the last half-day of the pilgrimage on a guided sightseeing tour of Saipan, organized by a local travel agency. The tour stopped at the sites related to the Japanese colonial era and the war, such as a former hospital, a rebuilt Shintō shrine, and the site of the civilian internment camp in southern Saipan. The touring pilgrims often supplemented (or interrupted) the explanations given by the tour guide, a Japanese mainlander who had lived in Saipan for decades. One participant was overcome with emotion at Saipan Shrine, where she had played as a young child living in the same neighbourhood. There, she began telling the guide, her accompanying daughter, and fellow pilgrims that her entire family had survived the war and repatriated to Okinawa. For the last 70 years, she had longed to return to Saipan and thank the shrine's god on behalf of her family, because they believed that the god had protected them during the trying years of the battle, internment, and repatriation.

3 Curiously, these conversations rarely extended to sharing stories about their postwar lives in Okinawa, as if their lives had been suspended in the time-space of the colonial and wartime Marianas. 
In addition to the formal collective ceremony and group tour, some pilgrims conducted their own individual rituals during the trip. Many visited their childhood homes and/or the locations in which their family members had been killed. To conduct these private rituals, many pilgrims made great efforts to close the spatiotemporal distance between their deceased loved ones and themselves by asking for help from academic historians or those who had visited the island numerous times to find out the approximate location of their deceased family member's death prior to the trip. Others consulted with yuta, a spiritual shaman in Okinawa, before their trip to locate the locations of their family members' deaths (Allen 2002). ${ }^{4}$ Ms Takeko Yonaha was born in Naha, Okinawa, but her father moved the family to Saipan's southern district to become a tenant farmer for NKK. Her niece was killed by the US gunships' bombing in 1944. For the 2015 MRA pilgrimage, Ms Yonaha wanted to pray for her niece in a quieter setting than the official irei ceremony and pray for her friend's uncle who died off the coast of Saipan. On the fourth and final day of the trip, Dr. Yumiko Imaizumi (who has extensively researched the Okinawan and Japanese colonization of and migration to Micronesia), and I joined Ms Yonaha when she fulfilled her wishes. A local acquaintance of Dr. Imaizumi took a day off from her work and offered to give us a ride for the day. She had never met us, but having known a grandchild of a former Japanese settler was a good enough reason for her to help us. The first destination was the Okinawa Memorial Marker. Ms Yonaha told us that her prayer was rushed during the official irei ceremony, as she knew that the others were waiting their turns behind her, so she wanted to spend more time to pray for her niece's death. She burned Okinawan-style incense and uchikabi (mock money given to the dead for meeting their needs in the afterlife). It was a windy day, and she was having difficulty lighting the incense, so Dr. Imaizumi and I surrounded her to block the wind. Ms Yonaha placed water and Säta Andagì, or Okinawan donuts, in front of the cenotaph and read aloud a Buddhist prayer for about ten minutes, as three of us watched.

The next destination was the summit of Mount Tapochau, where the statue of Christ is located. It is an important site for Catholic Indigenous islanders, but it is also a popular tourist destination. After waiting for a group of Chinese tourists to leave the site, Ms Yonaha tried to light candles to pray for her friend's uncle. Due to the strong wind, however, she handed three of us unlit candles instead. All four of us silently prayed for ten seconds while holding the candles for Ms Yonaha's friend's uncle by looking over the southern shore of Saipan.

During these collective ceremonies and tours and individual excursions and rituals, the pilgrims often seek a sign of encounter with the souls of the dead. For instance, the MRA vice president, who emceed the Saipan ceremony, repeatedly mentioned the clear weather of that day as a sign that the souls of those Okinawans who had been killed during the Battle of the Marianas on the island were welcoming the visitors. Many former pilgrims I interviewed recalled what they believed to be supernatural phenomena they experienced during the pilgrimages: a sudden rain shower that interrupted a memorial ceremony; beautiful white birds perched on the memorial marker during prayers; and a sudden wave that washed away food offerings immediately after the pilgrims finished praying for their dead parents. Ms Michiko Iha, who was born in Okinawa but raised in Saipan, lost her father, two brothers, and a niece

4 Both collective and individual rituals followed the Okinawan mourning practices. Even the memorial marker in Tinian is modelled on a traditional Okinawan tomb, which is said to resemble a womb, a pathway between 'this' and 'that' worlds in the Okinawan spiritual worldview. Offering a prayer at the childhood home is also modelled on a similar ritual in Okinawa, as it is believed that people in this world are merely borrowing land from a god, and one must thank the god that lets you live there and keeps you and your family happy and healthy. 
during the Battle of Saipan and was captured by US soldiers after unsuccessfully trying to kill herself by diving into the sea. She has participated in more than thirty pilgrimages and recalled her first pilgrimage experiences in the 1970s: 'During my earlier trips to Saipan, I could see everyone who died there. I could see so many of them near the ireito (a cenotaph to pacify the war dead's souls).' These anecdotes, which they shared among themselves during the trip, created a strong bond with other participants, who were willing listeners and believers of their stories. These stories, however, also highlight the spatiotemporal paradox of pilgrimage to 'encounter,' 'retrieve,' and 'accost' the souls of dead loved ones: the trip enables pilgrims to come so close to, yet also remain so far from, the dead. ${ }^{5}$ The participants' sincere yet pained quests to encounter and retrieve the souls of their loved ones, quests which generate such stories of supernatural episodes, infuse their group pilgrimage with a shared spiritual purpose and facilitate the formation of solidary identity.

$$
* \quad * \quad *
$$

These ethnographic snapshots of pilgrimage provide glimpses of how collective identity among the pilgrims was formed, underpinned by their shared grief of having lost their loved ones in the war, and the shared desire to spiritually connect with the war dead's souls remaining in the place of death, through group travel. Additionally, these ritualistic performances during the trip helped the pilgrims create the shared memory of the colonial and wartime past among the colonial repatriates, and, in many instances, their accompanying children and grandchildren, who joined the trips to assist their aging parents and grandparents.

It is important to point out that what is generally missing in the mnemonic practices during annual pilgrimages to the Northern Marianas: the colonial Others, namely, Indigenous islanders and Korean labour migrants. The repatriates' collective remembering of the colonial past was accompanied by collective forgetting of the past and depoliticization of the collective memory. Even though the MRA leaders' speeches at the memorial ceremonies were dedicated to the war victims of all nationalities, including Korean migrant laborers, local islanders, and American soldiers, the pilgrims' conversations among themselves and personal prayers to their dead family members rarely mentioned Japanese imperialism overtly. Nor did they explicitly mention the exploitative system of the Marianas' colonial economy that discriminated against local islanders and Koreans, or the militarism of Imperial Japan that drove many Okinawan civilians to commit suicide rather than surrender. Pilgrims visited the sites where their family members or relatives died tragically during battle, but few visited the memorial markers dedicated to the Indigenous islanders who died in the war, or the American cemeteries for fallen soldiers. Because the pilgrims' intimate desire to encounter the souls of their dead family members underpinned this travel, therefore, the collective memory and mnemonic community generated through ritualistic travel (Sturken 1997) also screened the participants from acknowledging certain aspects of the past. As a result, the pilgrims often failed to view their own collective past as part of broader legacies of colonialism and war.

In addition to the shared sorrow among the pilgrims who suffered from the battles in the Northern Marianas, my interviewees pointed out the repatriates' shared sense of responsibility to pray for the family members and friends who had died on the islands. In Okinawan folk belief, which blends Indigenous nature and ancestor worship with the Buddhism and Confucianism brought into the Ryūkyū Kingdom (1429-1879) from Japan and China, the

5 Nishimura (2008b) articulates this paradox in his study of battlefield pilgrimage among the warbereaved family associations. 
world of the living and the world of the dead (gusō) are deeply connected. Further, the people living in this world are expected to keep paying respect to, communicating with, and pleasing the souls (mabui) of dead ancestors. The soul of the dead person is led into the family's turtleshell tomb, where the soul, after numerous soul-pacifying rituals, steadily turns into a spirit and, after the $33^{\text {rd }}$ annual pacifying ritual, into an ancestral god or ukami (Hamasaki 2005). Yuta often play a crucial role as intermediaries between the two worlds, as the dead speak through yuta's mouths to the living (Akamine 2002). Yuta not only helps the bereaved family members conduct the ceremonies properly but also serves as a folk healer and therapist (Allen 2002). Yuta's diagnosis (banji) of the client's physical ailments or other unusual conditions often points to insufficient or improper prayer and respect given to dead ancestors (known as the state of uganbusuku), which leaves the souls of the dead unable to turn peacefully into ancestral spirits and gods (Fujii 1978: 147; Hamasaki 2005: 10). Conversely, showing an abundant amount of respect and gratitude to the dead ancestors' souls by frequently and properly praying at the tomb, as yuta would suggest, is believed to provide good health and fortune to those who live in this world. One interviewee told me that she had consulted with multiple yuta when she was suffering from chronic fatigue, and their diagnoses were that she was suffering from uganbusuku. This is typical of the Okinawan masses' religio-spiritual attitudes towards the dead, as is this particular interviewee's declaration that her friend's good health and stable employment in old age were direct consequences of his numerous pilgrimages to the Marianas.

Many Okinawan repatriates believe that pilgrimages to the Northern Marianas are intended to pacify the souls of their dead relatives and friends because the lack of proper care might result in the suffering of both the living and the dead. In fact, most interviewees who had participated in the Marianas pilgrimages in the past told me that their primary purpose was to get as close to the places their family members died during the war as possible and to offer a prayer to console those souls still there. As stated, several Okinawan repatriates who had participated in the pilgrimages told me that they had witnessed ghosts of the war dead in Saipan and Tinian, especially near the cliffs from which many Japanese and Okinawan civilians jumped off to kill themselves. These souls, the Okinawan repatriates believe, were unable to leave the sites of their deaths and return to their family tombs. As a result, their tortured souls remained at the locations of their deaths in the form of ghosts, which yuta and others who possess strong spiritual capacity could see clearly (Hamasaki 2005: 11). In these private pacifying rituals at the presumed sites of their family members' or relatives' deaths, apart from the MRA's official group ceremonies conducted at the stone cenotaphs on Saipan and Tinian, individual pilgrims often conduct nujifa, or a rite to lead the restless soul (mabui) of the dead to the after-world. Typically, a family member of the deceased conducted nujifa, literally 'taking out the soul' from one location and moving it to another, after someone died outside his or her house. This ritual involves praying to the gods residing in the place of the death and asking their permission to take the soul out of there. Nujifa at the Northern Marianas is accompanied by unchike, or accosting, another ritual that transports the souls in a material object, such as a stone or incense, as a vehicle (yorishiro) to the family tomb in the shima, or natal community, in Okinawa (Inoue 2007: 169).

For many of the Okinawan pilgrims, in other words, the trip to the Northern Marianas represents much more than a mere journey of nostalgia. Indeed, the repatriates' stories of witnessing the wandering ghosts of the war dead in the Marianas, and the pilgrims' insistence that the survivors and relatives of the war dead must continue to visit and pray for their souls all indicate that it is not merely the memories of a nostalgically romanticized childhood 
and the agony of the war and repatriation that continue to unite the repatriates even after more than 60 years after the end of the war. Their collective identity as repatriates is crucially fortified by their shared belief that they are all forever attached to their dead Okinawan relatives and friends whose souls remain in the islands. And these deaths and the souls of the dead, more importantly, serve as an indispensable intermediary among the repatriates to maintain their collective memory and identity.

\section{Conclusion}

This article has attempted to make two central claims. First, it sought to demonstrate that the migrants of decolonization, such as those Okinawans who had migrated to, or been born and raised in, the Japanese mandate of Micronesia, including the Northern Mariana Islands, and were forced to 'return' to Okinawa after the violent Battle of the Marianas in 1944, could be considered as a diasporic population. They were displaced—twice-from 'home' under colonial and postcolonial conditions; they have maintained collective memory and myth about the romanticized vision of 'homeland' over the years; they initially sought to return to the Marianas under US rule; they experienced challenging years of re-establishing livelihood and getting accepted by the Okinawan locals after repatriation; and they have maintained a strong sense of empathy for and solidarity with each other.

Second, the article attempted to demonstrate the mechanisms of collective memory and identity maintenance by ethnographically analyzing ritualistic collective practices. Specifically, these were annual pilgrimages to the Marianas during which formal and informal rituals were held. In both sets of rituals, I argued, the deaths and souls of the dead played a critical intermediary role in forming and strengthening pilgrims' sense of solidarity with and empathy for each other. This is deeply rooted in Okinawan spirituality in regards to ancestors and souls of the dead.

The Okinawan repatriates as a diaspora who maintain collective identity through ritualistic pilgrimages to the Marianas, however, may not continue to exist beyond the repatriate generation. Like pied-noirs in France (Cohen 2002: 144), the repatriate generation is slowly disappearing and their children are not as committed to the memory of their parents' diasporic experiences, such as childhood on the islands, war and internment, and repatriation, despite the MRA leaders' effort to bring them into the organization, and the repatriates themselves bringing their children on the pilgrimages. While the Marianas pilgrimages may continue in the foreseeable future, the collective memory practices will inevitably change their forms as the new generation has 'naturally looser bonds to the memory' (ibid.) of the colonial and wartime Micronesia.

\section{References}

Ahonen, P. 2016, 'The German Expellee Organizations: Unity, Division, and Function,' in Vetriebene and Pieds Noirs in Postwar Germany and France: Comparative Perspectives, (eds) M. Borutta \& J. C. Jansen. Palgrave-Macmillan, New York: 115-132. https://doi.org/10.1057/9781137508416_6

Akamine, M. 2002, 'Amami, Okinawa no Sōsō Bunka: Sono Dentō to Hen'yō’ ['Funeral Culture of Amami and Okinawa: Its Tradition and Change'], in Soggi to Haka no Genzai: Minzoku no Hen'yō [Today's Funerals and Tombs: Changes in Folklore], (ed) Kokuritsu Rekishi Minzoku Hakubutsukan. Yoshikawa Kōbunkan, Tokyo: 2-27.

Allen, M. 2002, 'Therapies of Resistance?: Yuta, Help-Seeking, and Identity in Okinawa,' Critical Asian Studies, vol. 34, no. 2: 221-242. DOI: https://doi.org/10.1080/14672710220146215 
Aniya, M. 1995, 'Sengo no Kaigai Hikiage (Repatriation from Overseas after the War), in In'numi kara: 50-nen me no Shögen [From In'numi: Testimonials after 50 Years], (ed) Okinawa-shi. Okinawa City Government, Okinawa: 12-16.

Awazu, K. 2010, 'Baikai sareru Kōi to shite no Kioku: Okinawa ni okeru Ikotsu Shūshū no Gendai-teki Tenkai' ['Memory as a Mediated Action: Collecting Remains in Okinawa in Contemporary Japan'], Shükyō to Shakai, vol. 16: 3-31.

Badone, E., \& Roseman, S. R. 2004, Intersecting Journeys: The Anthropology of Pilgrimage and Tourism. University of Illinois Press, Urbana, IL.

Baussant, M. 2016, 'Pied-Noir Pilgrimages, Commemorative Spaces, and Counter-Memory,' in Vertriebene and Pieds-Noirs in Postwar Germany and France: Comparative Perspectives, (eds) M. Borutta, M. \& J. C. Jansen. Palgrave-MacMillan, New York: 153-172. DOI: https://doi. org/10.1057/9781137508416_11

Borutta, M. \& Jansen, J. C. (eds) 2016, Vetriebene and Pieds-Noirs in Postwar Germany and France: Comparative Perspectives. Palgrave-Macmillan, New York.

Buettner, E. 2016, Europe after Empire: Decolonization, Society, and Culture. Cambridge University Press, Cambridge. DOI: https://doi.org/10.1017/CBO9781139047777

Cerulo, K. A. 1995, Identity Designs: Sights and Sounds of a Nation. Rutgers University Press, New Brunswick.

Cohen, E. 1992, 'Pilgrimage and Tourism: Convergence and Divergence,' in Sacred Journeys: The Anthropology of Pilgrimage, (ed) A. Morinis. Greenwood Press, Westport: 47-61.

Cohen, R. 1997, Global Diasporas: An Introduction. University of Washington Press, Seattle. DOI: https:// doi.org/10.4324/9780203228920

Cohen, W. 2002, 'Pied-Noir Memory, History, and the Algerian War,' in Europe's Invisible Migrants, (ed) A. L. Smith. Amsterdam University Press, Amsterdam: 129-146.

Collins-Kreiner, N., \& Gatrell, J. D. 2006, 'Tourism, Heritage and Pilgrimage: The Case of Haifa Baha'i Gardens,' Journal of Heritage Tourism vol. 1, no. 1:32-50. DOI: https://doi. org/10.1080/17438730608668464

Collins-Kreiner, N. \& Kliot, N. 2000, 'Pilgrimage Tourism in the Holy Land: The Behavioral Characteristics of Christian Pilgrims,' GeoJournal, vol. 501: 55-67. DOI: https://doi. org/10.1023/A:1007154929681

Connerton, P. 1989, How Societies Remember. Cambridge University Press, Cambridge. DOI: https://doi. org/10.1017/CBO9780511628061

Cooper, F. 2002, 'Postcolonial Peoples: A Commentary,' in Europe's Invisible Migrants, (ed.) A. L. Smith. Amsterdam University Press, Amsterdam: 169-184.

Eade, J., \& Sallnow, M. J. 1991, Contesting the Sacred: The Anthropology of Christian Pilgrimage. Routledge, London.

Figal, G. 2007, 'Bones of Contention: The Geopolitics of "Sacred Ground” in Postwar Okinawa,' Diplomatic History vol. 31, no. 1: 81-109. DOI: https://doi.org/10.1111/j.1467-7709.2007.00592.x

Frey, N. L. 1998, Pilgrim Stories: On and Off the Road to Santiago. University of California Press, Berkeley.

Fujii, M. 1978, 'Senzo Kuyō,' in Okinawa no Gairai Shūkyō: Sono Juyō to Hen’yō [Religions in Okinawa with External Origins: Acceptance and Change], (ed) N. Kubo. Tokyo: Kōbundō: 143-182. 
U T S

e PRES S

Graburn, N. H. H. 1977, 'Tourism: The Sacred Journey,' in Hosts and Guests: The Anthropology of Tourism, (ed.) V. L. Smith. University of Pennsylvania Press, Philadelphia: 33-47.

Halbwachs, M. 1992, On Collective Memory. Trans. \& ed. L. A. Coser. University of Chicago Press, Chicago.

Hamai, K. 2008, 'Sengo Nihon no Kaigai Senbotsusha Irei: 1950 nen-dai Ikotsu Shūshū-dan no Haken Kei'i to "Senbotsu Nihonjin no Hi" no Konryū' ['Overseas Memorials for Japanese War Dead in the Postwar Period: The Process of Dispatching Parties to Collect Remains in the Southern Regions and the Erection of Memorial Monuments for Japanese War Dead in the 1950''], Shirin, vol. 91, no. 1: 198-229.

Hamasaki, M. 2005, 'Okinawa ni okeru gurīfukea to shite no nujifa nit suite' ['Nujifa as a Grief Care in Okinawa'], Ningen Kagaku 16: 1-20.

Imaizumi, Y. 2005, 'Nan’yō Guntō Hikiage-sha no Dantai Keisei to Sono Katsudō: Nippon no Haisen Chokugo wo Chūshin to shite' ['Problems Among the Postwar Repatriates from the Japanese Mandate of Micronesia: Their Mainland and Okinawan Associations'], Shiryō Henshüshitsu Kiyō, vol. 30: 1-44.

Inoue, C. 2007, 'Okinawa kara Tenian e: Futatsu no Kokyō/Kikansha-tachi no Sengo' ['From Okinawa to Tinian: Two Homelands/The Postwar Era of the Repatriates'], Okinawa Sutairu, vol. 18: 168-169.

Irei, S. 1995, 'Jipan wo Kakaete Saipan kara In'numi e' ['From Saipan to In'numi with a Pair of Jeans in My Arms'], in In'numi kara: 50-nen me no Shögen (From In'numi: Testimonials after 50 Years), (ed) Okinawa-shi. Okinawa City Government, Okinawa: 48-67.

Kitamura, T. 2005, 'Senshisha e/tono Tabi: Okinawa Senseki Junrei ni okeru "Izoku no Komyunitasu” ['Pilgrimage to/with the War Dead: "Communitas of the War Bereaved" of the Battle of Okinawa'], Ningen Kagaku Kenkyü, vol. 18, no. 2: 137-52.

2009, Shisha-tachi no Sengo-shi: Okinawa Senseki wo meguru Hitobito no Kioku [A Postwar Ethnography of the War Dead in Okinawa]. Ochanomizu Shobō, Tokyo.

Kwon, H. 2006, After the Massacre: Commemoration and Consolation in Ha My and My Lai. University of California Press, Berkeley. DOI: https://doi.org/10.1525/california/9780520247963.001.0001

Lubkemann, S. C. 2002, 'Race, Class, and Kin in the Negotiation of "Internal Strangerhood" Among Portuguese Retornados, 1975-2000,' in Europe's Invisible Migrants, (ed) A. L. Smith. Amsterdam University Press, Amsterdam: 75-94.

Nakayama, K. 2008, 'Senbotsusha Irei Junpai Oboegaki: Chiba-ken, Tochigi-ken Gokoku Jinja Shusai, 'Senbotsusha Irei Junpai' no Jirei kara' ['A Note on Pilgrimage for the War Dead: A Case Study of the Pilgrimage for the War Dead" Organized by the Chiba Prefecture and Tochigi Prefecture Gokoku Shrines'], Kokugakuin Daigaku Kenkyū Kaihatsu Suishin Sentā Kenkyū Kiyō, vol. 2: 171-215.

Nishimura, A. 2008a, 'Ikotsu e no Omoi, Senchi e no Omoi: Senshisha to Seizonsha-tachi no Sengo' [Feelings for the Remains, Feelings for the Battlefields: The Postwar Era for the Fallen Soldiers and Survivors'], Kokuritsu Rekishi Minzoku Hakubutsukan Kenkyū Hōkoku, vol. 147: 77-90.

2008b, 'Ikotsu Shūshū, Senchi Hōmon to Senshisha Izoku: Shisha to Seija no Ji-kūkan-teki Hedatari ni Chūmoku shite' ['Bone Collection, Battlefield Visit, and the Families of the War Bereaved: Focusing on the Spatiotemporal Divide between the Dead and Living'], Shörwa no Kurashi Kenkyü, vol. 6: $39-52$.

Olick, J. K. 2003, 'Introduction,' in States of Memory: Continuities, Conflicts and Transformations in National Retrospection, (ed) J. K. Olick. Duke University Press, Durham: 1-16. DOI: https://doi. org/10.1215/9780822384687-001 
Saipan-kai 1994, Saipan-kai-shi Dai-2 Gō: Kokoro no Furusato Saipan [Saipan Club Journal Volume 2: Saipan is Our Hearts' Homeland]. Saipan-kai, Naha, Japan.

Schwartz, M. 2016, 'Assimilation versus Incorporation: Expellee Integration Policies in East and West Germany after 1945,' in Vertriebene and Pieds-Noirs in Postwar Germany and France: Comparative Perspectives, (eds) M. Borutta \& J C. Jansen. Palgrave-Macmillan, New York: 73-94.

Shimamura, Y. (ed) 2013, Hikiage-sha no Sengo [The Repatriates' Postwar]. Shin'yō-sha, Tokyo.

Shimojima, T. 2012, Higō no Seija-tachi: Shüdan Jiketsu Saipan kara Manshū e [The Fateful Survivors: Mass Suicide, from Saipan to Manchuria]. Iwanami Shoten, Tokyo.

Smith, A. L. (ed) 2002a, Europe's Invisible Migrants. Amsterdam University Press, Amsterdam. DOI: https://doi.org/10.5117/9789053565711

2002b, 'Europe's Invisible Migrants,' in Europe's Invisible Migrants, (ed) A. L. Smith. Amsterdam University Press, Amsterdam: 9-32. DOI: https://doi.org/10.5117/9789053565711

Spillman, L. P. 1997, Nation and Commemoration: Creating National Identities in the United States and Australia. Cambridge University Press, Cambridge. DOI: https://doi.org/10.1017/CBO9780511520938

Sturken, M. 2007, Tourists of History: Memory, Kitsch, and Consumerism from Oklahoma City to Ground Zero. Duke University Press, Durham. DOI: https://doi.org/10.1215/9780822390510

Tamanoi, M. A. 2009, Memory Maps: The State and Manchuria in Postwar Japan. University of Hawai'i Press, Honolulu.

Toriyama, J. 2013. Okinawa: Kichi Shakai no Kigen to Sōkoku [Okinawa: The Origin and Conflict of Military Base Society]. Keisō Shobō, Tokyo.

Turner, V. 1973, ‘The Center Out There: Pilgrim's Goal,' History of Religions, vol. 123: 191-230. DOI: https://doi.org/10.1086/462677

Vélez, R. V. 2008, “Because the Story Does Not Allow Us ...”: Collective Memory and the Articulation of Mobilization Narratives in the Antimilitary Movement of Vieques (1999-2003),' PhD Dissertation, State University of New York, Albany.

Watt, L. 2009, When Empire Comes Home: Repatriation and Reintegration in Postwar Japan. Harvard University Asia Center, Cambridge, MA. DOI: https://doi.org/10.2307/j.ctt1x07w3r

Weger, W. 2016, 'Homeland Corners: Memories, Objects, and Emotions of Expellees in Postwar West Germany,' in Vetriebene and Pieds-Noirs in Postwar Germany and France: Comparative Perspectives, (eds) M. Borutta \& J. C. Jansen. Palgrave-Macmillan, New York: 193-211.

Werbner, R. 1989, Ritual Passage, Sacred Journey. Smithsonian Institute, Washington.

Willems, W. 2002, 'No Sheltering Sky: Migrant Identities of Dutch Nationals from Indonesia,' in Europe's Invisible Migrants, (ed) A. L. Smith. Amsterdam University Press, Amsterdam: 33-60.

Zerubavel, E. 1996, 'Social Memories: Steps to a Sociology of the Past,' Qualitative Sociology, vol. 19, no. 3: 283-299. DOI: https://doi.org/10.1007/BF02393273

Zerubavel, Y. 1995, Recovered Roots: Collective Memory and the Making of Israeli National Tradition. University of Chicago Press, Chicago. 